\title{
¿Quiénes son los
}

mexicanos? Las primeras

descripciones anglosajonas

sobre los habitantes de un

nuevo país, 1821-1846

Raúl Bringas Nostti ${ }^{1}$
raul.bringas@udlap.mx

DOI: http://orcid.org/0000-0001-6382-0581
Who are the Mexicans? The first

Anglo-Saxon descriptions of the

inhabitants of a new country, 1821-1846

\section{Resumen}

Entre 1821 y 1846 numerosos cronistas anglosajones visitaron el México recién independizado. Describir a los mexicanos fue uno de sus mayores intereses. Sus textos son una fuente invaluable de información sobre el México de entonces. Los viajeros no solo servían a un interés cultural, pues sus descripciones cumplían una función geopolítica. Este artículo presenPalabras clave: México, Estados Unidos, Gran Bretaña, crónica viajera, mexicanos.

\section{Abstract}

Between 1821 and 1846, many Anglo-Saxon chroniclers visited newly independent Mexico. Describing the Mexicans was one of their greatest interests. Their texts are an invaluable source of information about the Mexico of that period. Travelers not only served a cultural interest; their descriptions fulfilled a geopolitical func- ta una entretenida compilación del juicio demoledor de los escritores anglosajones que permite exponer su intención geopolítica de exhibir la degradación sociocultural, que no racial, de los mexicanos. Se advierte el propósito de los cronistas de justificar un mayor involucramiento anglosajón en México con supuestas aspiraciones de redención. tion. This article presents an entertaining compilation of the devastating judgment of Anglo-Saxon writers. By doing so, it demonstrates the geopolitical intention of exhibiting the sociocultural, not racial, degradation of the Mexicans. The purpose of the chroniclers was to justify a greater Anglo-Saxon involvement in Mexico for supposed redemption schemes. Key words: Mexico, United States, Great Britain, traveler chronicle, Mexicans.

1 Universidad de Las Américas Puebla, México.

Ex-Hacienda Santa Catarina Mártir S/N, C.P. 72810, San Andrés Cholula, Puebla, México. 


\section{Introducción}

En la segunda década del siglo XIX y en las dos subsecuentes, Hispanoamérica capturó la atención de los círculos empresariales y gubernamentales de los dos grandes países anglosajones, Estados Unidos y Gran Bretaña. Con carácter urgente, las élites políticas y económicas demandaban información sobre las particularidades de las nuevas naciones que recién se habían independizado de España. Se sabía que el inmenso continente del que España se retiraba no era homogéneo. Las antiguas colonias ibéricas tenían un carácter tan contrastante como la geografía misma de un territorio que se extendía desde el inclemente desierto de la actual Utah hasta las heladas tierras colindantes con la Antártida.

El interés por Hispanoamérica contaba con dos vertientes. Por un lado, se inspiraba en la curtida tradición de la crónica viajera anglosajona, pulida a lo largo de los siglos. Por cientos de años, el lector anglosajón se había aficionado a descripciones sobre otras tierras, desde fábulas y anécdotas hasta explicaciones orográficas y biológicas. La otra vertiente surgía de la geopolítica. La amenaza de reconquista por parte de la Santa Alianza obligaba a gobiernos y empresarios a contar con información precisa sobre las particularidades de los nuevos países como estrategia para evaluar riesgos y oportunidades.

México, que había sido la más importante colonia en el imperio español, fue el objetivo central de los cronistas anglosajones, ansiosos por cumplir su doble propósito cultural y geopolítico. El cuarto de siglo que corrió entre el nacimiento del país en 1821 y el inicio de la Guerra de 1846 con Estados Unidos fue la infancia de México. Se trató de un periodo en el que la debilidad institucional y la carencia de identidad nacional amenazaban la viabilidad del país. Los dos grandes países anglosajones, en su rivalidad mutua y en su disputa conjunta contra las potencias absolutistas en el marco de la Doctrina Monroe, perseveraron en la recopilación de información sobre México. El resultado fue una nutrida serie de crónicas de viajeros que describieron la realidad mexicana.

El presente artículo selecciona y revisa crónicas anglosajonas en sus versiones originales, sin las alteraciones realizadas en ediciones posteriores o traducciones. Salvo tres excepciones no pertinentes al tema, representan la totalidad de las crónicas viajeras anglosajonas sobre México, publicadas en forma de libro y referentes al periodo que corre desde el nacimiento del país a la Guerra de 1846. Este conflicto bélico trajo consigo un corte de caja; es decir, una segunda gran oleada de cronistas anglosajones, en su mayoría militares con objetivos diferentes a los de los primeros narradores (Singletary, 1962, pp. 166-168). Dada la imposibili- 
dad de analizar los múltiples temas que los primeros cronistas abordaron, este artículo se concentra en uno de los tópicos más interesantes: sus impresiones sobre los ciudadanos de México. Tres vertientes los cautivaron: las particularidades raciales de los mexicanos, las relaciones entre estos y su personalidad/comportamiento.

El artículo presenta al lector una compilación de los juicios externados por los cronistas anglosajones sobre los mexicanos. A partir de estos juicios se elabora una interpretación acerca de los verdaderos motivos que los inspiraron. La crónica anglosajona no era un ave rara; junto con ella convivían lúcidas obras de viajeros franceses, germanos y españoles. Como se advierte en líneas posteriores, se elige la crónica en lengua inglesa porque tenía un objetivo preciso que le otorgaba un cuerpo distintivo: el de la hermandad anglosajona enfrentada a Europa continental. Al presentar el estado de lamentable degradación de la población mexicana y sus grandes virtudes adormiladas, la crónica anglosajona procuraba resaltar los daños provocados por tres siglos de absolutismo europeo que amenazaba con retornar de la mano de la Santa Alianza. El objetivo de los cronistas fue justificar un mayor involucramiento en México con un supuesto propósito redentor, siempre ligado a los intereses geopolíticos de Estados Unidos y Gran Bretaña.

\section{¿Es la crónica viajera una fuente confiable de información?}

El historiador Drewey Wayne Gunn (1974, pp. 14-33) realizó una extensa compilación sobre los cronistas anglosajones que visitaron México. Una parte de su obra se concentró en aquellos viajeros que recorrieron el país cuando este atravesaba su primer cuarto de siglo de vida. Estos trabajos junto con los de cronistas de la Europa continental que también visitaron el país, se convirtieron con el paso de los años en una valiosa fuente de información sobre el México de entonces. Sin embargo, cabe preguntar hasta qué punto la crónica extranjera otorga una visión imparcial, certera y, por lo tanto, confiable sobre lo que acontecía en determinado momento histórico. A fin de cuentas, los viajeros cargaban con prejuicios y perseguían muy particulares intereses nacionales y hasta personales.

Juan Antonio Ortega y Medina (1955), en su obra ya clásica, México en la Conciencia Anglosajona, recalcó la vastedad de la crónica en lengua inglesa y subrayó el particular pragmatismo que la distinguía de otras crónicas. La consideró irremplazable porque "transcurre ininterrumpida a lo largo de cuatro siglos" sin "síntomas de senectud o apatía" (p. 9). Pero la juvenil vitalidad de la crónica anglosajona de ninguna manera le otorgaba el don de la veracidad ni la hacía más confiable que las narra- 
ciones de los europeos continentales. Independientemente de su origen nacional, el cronista extranjero dejaba entrever su etnocentrismo, fuente del juicio de valor. En su obra sobre Carlo Vidúa, viajero procedente del Piamonte que pretendió dar la vuelta al mundo y recorrió México en 1826, Luis Alberto De la Garza (2003, pp. 26-31) expresó cómo hasta los espíritus decimonónicos más libres vivían con prejuicios. Vidúa, hombre de mente abierta y ansioso por lanzarse a los mares, tuvo que desafiar el concepto del "Noteentiendo". Lo hizo en partida doble: tanto en la búsqueda de su identidad italiana, como en la "confrontación que marca al viajero".

Además del etnocentrismo, el tiempo de residencia en el país; es decir, el grado de compenetración con la realidad mexicana, modificaba la manera de observar y juzgar. José Enrique Covarrubias (1998) separó la "literatura de viajeros", a la que tan apasionado era Ortega y Medina, de la crónica del extranjero inmigrado a México. Covarrubias (1998) afirmó que existía una evidente "superioridad del inmigrante frente al mero itinerante". Mientras los viajeros anglosajones tendían a cumplir la función de enviado "diplomático o mercantil" transitorio, el europeo continental se empapaba más de México (pp. 8-9). Pese a que una prolongada residencia permitía modificar la visión del extranjero, al anglosajón le era más difícil desprenderse de su etnocentrismo a ultranza que a los europeos continentales. Jorge Silva (1946), en su obra sobre los viajeros franceses en México, mostró que, sin dejar de ser etnocentristas, los continentales tenían una capacidad para la empatía ausente en los anglosajones. Una idea similar expresó Chantal Cramaussel (1998); atribuyó el juicio lapidario del cronista anglosajón a una centenaria tradición de denuncia a España y su política opresora.

Si bien el cronista anglosajón parecía ser más categórico y menos empático que el europeo continental, a fin de cuentas, la personalidad y los intereses de un viajero en particular incidían tanto o más que su nacionalidad. Por ejemplo, Brigitte Boehm de Lameiras (1973) analizó la percepción que los extranjeros tuvieron sobre los indígenas y mostró cómo los textos de viajeros de una misma nacionalidad podían ofrecer diferentes conclusiones. Más aún, entre los propios viajeros estadounidenses decimonónicos abundaron las temáticas y perspectivas contrastantes, y sus textos no siempre manifestaron el esperado rigor anglosajón (Cole, 1978). Incluso, en una vuelta de tuerca que revela la magnitud de la influencia de la personalidad y de los intereses del individuo, Ana Lau Jaiven (1994) expuso cómo, en un tópico tan específico como la visión sobre la mujer mexicana de la primera mitad del siglo XIX, las crónicas anglosajonas variaban. Esto a pesar de que las escribían individuos muy similares hasta en su condición sociocultural, pues se trataba de viajeros llegados 
a México con "el objetivo de entablar negocios y obtener ventajas para el intercambio comercial y mercantil" (p. 371).

Ante la fuerza de la psicología y de los intereses personales, un europeo continental podía convertirse en un observador más implacable que el cronista anglosajón. Este fue el caso del frío cónsul germano Carl Wilhelm Koppe, residente en México entre 1830 y 1832. Pintó, según Karl Kohut (2010), una "visión sombría del presente mexicano", impregnada de "intolerancia religiosa y chauvinismo" (p. 162). Más allá de la profunda introspección personal que marcaba los relatos, habría incluso que considerar si algo tan trivial como el buen o mal trato recibido por el cronista durante su viaje incidió en su percepción. Mary Louise Pratt (2008), particularmente interesada en los viajeros que recorrieron la América española, argumentó acerca de la importancia del papel de "la gente que recibió a estos visitantes" (p. 5). Las particularidades personales del observador, aunadas a su propia experiencia de viaje, nunca dejaron de ser una fuente de subjetividad. Por ello, Walther Bernecker (2003) concluyó que la "ciencia histórica" ya ha desechado "la idea ingenua y simplista" de que los "relatos de viajeros son una mera reproducción de la realidad". Esto obliga a "considerar las limitaciones de la percepción de los viajeros" (p. 42) y por lo tanto, a ser rigurosos en el uso de las crónicas como fuente de información.

Las crónicas sobre el primer cuarto de siglo de vida de México ejemplifican los riesgos de aceptar como precisa la visión de un viajero en particular. Se trata de textos muy diversos, que por consiguiente ofrecen un abanico de opiniones y conclusiones (Gardiner, 1952). Pero la visión prejuiciada, de la que no escapaba ningún cronista, no disminuye el valor de la crónica como herramienta para escribir historia. La fortaleza de los relatos de viajeros radica, según Margarita Pierini (2012), en experimentarlos "como discurso literario". Esta concepción permite utilizarlos como una fuente de variadas posibilidades históricas, desde el placer de la anécdota hasta la rigurosa condena etnocentrista, sin olvidar la aventura personal. Desde una perspectiva más científica, la inevitable subjetividad del cronista extranjero permite al historiador la "confrontación y comparación con los otros", como estrategia "para saber quiénes somos nosotros mismos" (De la Garza, 2003, pp. 23-24). Las crónicas de este artículo son eso: visiones cuasi literarias que no por ello pierden su valor como herramienta para la interpretación.

\section{La crónica anglosajona en el siglo XIX}

En 1821, las recopilaciones etnográficas sobre la Nueva España realizadas por los frailes españoles no cubrían la necesidad anglosajona de in- 
formación. Escritas en su mayoría durante el siglo XVI, ya eran obsoletas. Además, la información contenida en ellas no resultaba atractiva para el lector anglosajón que consideraba a la crónica española soporífera, reiterativa, cargada de propaganda papista y carente de sarcasmo individualista. Este lector exigía chascos anecdóticos, inflexiones del carácter humano, descripciones del paisaje y aventuras gastronómicas, entre otras curiosidades (Whittaker, 1824).

Para el siglo XIX, la literatura en lengua inglesa contaba con una sólida tradición de viajeros que describían las particularidades de pueblos distantes. Se reimprimían sin cesar las magníficas crónicas de Richard Hakluyt, Edward Terry o James Cook, por nombrar solo tres viajeros destacados. La segunda mitad del siglo contemplaría la extraordinaria obra del cronista Richard Francis Burton, uno de los autores favoritos del literato argentino con mente británica Jorge Luis Borges (Levine, 2012, pp. 21-27). Desde el lejano año de 1599, un suizo había argumentado que la fuerza de la crónica viajera en lengua inglesa se explicaba porque los anglosajones viajaban poco y preferían leer sobre otros pueblos en la comodidad de sus casas (Sherman, 2002, p. 20).

La industria editorial anglosajona demandaba crónicas sobre las características físicas, costumbres y particularidades de los habitantes de las excolonias españolas, en particular de los mexicanos. Exigía la visión de viajeros de habla inglesa y usaba como referente la exitosa obra del dominico inglés Thomas Gage (1677) sobre la Nueva España del siglo XVII. Por ello, a principios del siglo XIX, el libro del explorador prusiano Alexander von Humboldt (1814), quien viajó por la Nueva España, hipnotizó a la élite cultivada en Gran Bretaña y Estados Unidos. Si bien Von Humboldt cargaba con el peso de la metódica cultura germana, contaba con un espíritu anglosajón que se reflejaba en su narrativa y hasta en su conversación, en la que transitaba del alemán al inglés y de este al alemán sin que lo advirtiera (Stoddard, 1859, p. 458). Es probable que el éxito de la obra de Von Humboldt haya sido un catalizador para una legión de imitadores anglosajones.

La descripción que Von Humboldt realizó sobre la Nueva España no bastó para aplacar el interés de estadounidenses y británicos. El presidente Thomas Jefferson mantendría una nutrida correspondencia con el prusiano en la que la Nueva España y México continuarían siendo temas recurrentes (Rebok, 2014). Jefferson era solo un personaje notorio entre los miles de lectores que imploraban por más descripciones de primera mano. El nacimiento de México incrementó la sed de información que los editores interpretaron como una oportunidad comercial y los hombres de gobierno como una necesidad geopolítica. Los viajeros de habla inglesa 
actuaron con tal persistencia que en el primer cuarto de siglo de existencia de México predominaron las crónicas anglosajonas (Bernecker, 2003, p. 40). La dedicación y el entusiasmo que caracterizaron a los cronistas anglosajones evidenciaban un propósito que superaba el interés literario y que su prosa misma confirmaba: la estrategia geopolítica.

\section{La crónica como instrumento geopolítico}

La desaforada curiosidad por conocer cómo eran los nuevos países hispanoamericanos no solo obedecía a una inquietud cultural. Ante el vacío de poder dejado por España al retirarse de sus colonias, inició una pugna entre las mayores potencias por ocupar posiciones económicas y políticas en Hispanoamérica. La Santa Alianza, conformada por Prusia, Rusia y Austria en 1815, armó un ambicioso plan para recolonizar México y el subcontinente americano, aprovechando la debilidad de los países recién nacidos. En 1822 ya era palpable la preocupación estadounidense ante el intento europeo de "disponer de los destinos de aquellos países que comprenden lo que era la América española" (Niles, 1825, p. 229). Sin suficiente fuerza militar, Estados Unidos precisaba de una alianza con Gran Bretaña para frenar a las potencias absolutistas.

Los estadounidenses sabían que en Londres reinaba la preocupación, pues "el éxito de la Santa Alianza sería fatal para el poder británico" (Duane, 1824, p. 5). Sin embargo, en Washington prevalecía la desconfianza histórica a una alianza con una monarquía. Cuando Gran Bretaña propuso a Estados Unidos una declaración conjunta que prohibiera la recolonización de Hispanoamérica basada en la "afinidad" anglosajona, los estadounidenses usurparon la idea (Schake, 2017, pp. 47-52). En 1823, el presidente James Monroe efectuó dicha declaración sin notificación previa a los británicos. Nació así la Doctrina Monroe, que además de amenazar a la Santa Alianza sermoneó a la Gran Bretaña, madre del proyecto de contener la recolonización. Los intereses geopolíticos de las potencias anglosajonas las convertían en acérrimas rivales en América, pero las unían en defensa de la independencia de las nuevas naciones hispanoamericanas.

La conciencia de la amenaza de la Santa Alianza sobre Hispanoamérica, aunada a la propia rivalidad británico-estadounidense, impulsó la necesidad de información acerca de los nuevos países. No fue casual que los cronistas anglosajones comenzaran a arribar a México justo cuando la Santa Alianza se tornaba más agresiva. La tradición anglosajona de crónicas viajeras no bastaba para explicar el súbito deseo por conocer Hispanoamérica. Como bien lo afirmara un congresista en Washington, 
"ningún país puede ofrecernos más ricas ventajas comerciales tan a nuestro alcance que las repúblicas de la América española" (U.S. Congress, 1831, p. xxxv). La geopolítica inspiró la crónica sobre México tanto o más que la propia tradición literaria. Esto esclarece por qué, salvo un solo caso, las más importantes crónicas anglosajonas sobre el primer cuarto de siglo de vida de México surgieron de la pluma de diplomáticos, militares u hombres de negocios. ${ }^{2}$ Los simples curiosos brillaron por su ausencia.

Los cronistas anglosajones que visitaron México comprendían la involuntaria alianza que Estados Unidos y Gran Bretaña habían forjado. Lo habían entendido incluso desde antes de que México naciera. A mediados de 1821, un conocido aventurero ya había anticipado que Estados Unidos y Gran Bretaña se opondrían a una reconquista española (Robinson, 1821, p. 324). La crónica anglosajona sobre el México independiente no renunciaría a esta misión geopolítica. Conscientes de sus afinidades culturales y de su tradición liberal, británicos y estadounidenses confiarían en las crónicas de la otra parte. Esto explica por qué un libro muy crítico de los británicos, publicado en Filadelfia, se reimprimió de inmediato y con mucho éxito en Londres (Poinsett, 1824, 1825). A fin de cuentas, la visión sobre México resultaba netamente anglosajona: las semejanzas en análisis y conclusiones eran asombrosas.

Gracias al interés geopolítico anglosajón, México cuenta con copiosas descripciones de sus primeros años de vida. La aspiración geopolítica no oscureció la brillante tradición de la crónica viajera anglosajona, sino todo lo contrario. Hombres como George Lyon, Charles Latrobe o Waddy Thompson eran amantes de la literatura, la anécdota y el conocimiento. Utilizaron buena parte de su tinta en su vistoso fresco sobre el país, describiendo desde las bellezas naturales hasta la rareza de sus habitantes. En sus crónicas se despliega, cruel, un retrato tajante sobre los mexicanos de entonces. Fue, sin duda, una visión racista, pero que por ello plasma a los mexicanos con un implacable rigor y alguna verdad ocasional.

\section{Particularidades físicas de los mexicanos}

En una época con escasa y deficiente información visual, ninguno de los cronistas anglosajones que describieron la infancia de México sabía con exactitud, antes de su llegada, cómo era un indígena, un mestizo o, in-

La excepción fue la escocesa Frances Erskine Inglis. Si bien favoreció una mayor influencia anglosajona sobre México, su análisis no revela una sistemática visión geopolítica (Calderón de la Barca, 1843). 
cluso, un mexicano de origen ibérico. Así que su primer interés en cuestiones sociales fue describir las particularidades físicas de los mexicanos. Quienes más tinta merecieron fueron los indígenas, que en la primera mitad del siglo XIX constituían la mayoría de la población. Desde la perspectiva anglosajona, eran el elemento más exótico.

Las opiniones sobre las características físicas de los indígenas rara vez fueron generosas. Joel Poinsett (1825), ministro plenipotenciario estadounidense en México, los definió como "más oscuros que aquéllos de nuestras fronteras", con pelo "lacio y lustroso, labios bastante gruesos, nariz pequeña y ojo inclinado hacia arriba como los chinos y mongoles", por lo que "no son una raza muy favorecida" (pp. 107-108). Waddy Thompson (1846), también ministro plenipotenciario de la potencia del norte, vio en los indios mexicanos las mismas "peculiaridades físicas" presentes en los indios estadounidenses, solo que "mucho más pequeñas" (p. 166). El británico George Lyon (1828), contratado por la compañía Real del Monte para laborar en el sector minero, fue inclemente y comentó que los indios conformaban "una raza sin chiste y fea, en su mayor parte mal formada, y cuya apariencia torpe se incrementa por la costumbre de caminar con los pies hacia adentro" (p. 199).

La apariencia física de los indígenas reflejaba las deficiencias en sus órganos internos. Se les atribuía un cerebro pequeño que explicaba su escasa capacidad intelectual. George Frederick Ruxton (1847), explorador del ejército británico que murió de disentería durante su viaje, los consideró deficientes tanto "en organización física como moral", "inferiores a la mayoría de las razas en fuerza corporal" y por ello los ubicó en un "rango decididamente bajo en la escala de la humanidad" (p. 105). Con similares observaciones, el viajero inglés Robert William Hardy (1829), quien visitó México con la comisión de encontrar bancos de perlas y obtener concesiones para su explotación, afirmó que el "salvaje" indígena mexicano, en particular el del norte del país, mostraba "la imperfección del intelecto humano", por lo que él "[...] y no el mono, es el vínculo intermedio entre el hombre civilizado y la creación bruta" (pp. 353-354).

Como hombres, los cronistas anglosajones prestaron especial atención a la mujer indígena. Edward Penny (1828), inglés que viajó por México durante tres años explorando oportunidades comerciales, fue contundente: "sus rasgos y la expresión de su rostro son desagradables y son, sin excepción, la más fea raza de mujeres que he visto". Observó que a "los quince años empiezan a verse viejas y a los treinta son casi monstruos de fealdad; cualquier excepción sería considerada un fenómeno" (p. 64). El astrónomo, explorador y oficial del ejército británico Mark Beaufoy (1828) también comentó que las indígenas perdían "sus pretensiones a la belle- 
za a los dieciséis o diecisiete años de edad", algo lamentable porque en tres años no había encontrado más de "una docena" guapas y "con buenas figuras" (p. 128). Más escueto, Poinsett (1825) sentenció: "no están tan bien formadas, tienen facciones duras" (pp. 107-108).

La célebre escocesa Frances Erskine Inglis, marquesa Calderón de la Barca (1843, vol. 1), esposa del ministro español Ángel Calderón de la Barca, fue solidaria con su género y defendió a la mujer indígena, destacando sus "magníficos ojos negros, un cabello oscuro muy fino [...] y pequeños pies bien torneados". Sus dos defectos eran un cuerpo "demasiado pequeño y gordo" y el color de su piel, que no tenía ni el "olivo claro de los españoles, ni el moreno brillante de los italianos" (p. 150). Más sutil que cualquier otro cronista fue el comerciante de Baltimore, Brantz Mayer (1847), secretario de la legación diplomática estadounidense en México, quien aseguró que a la indígena mexicana no se le podía juzgar con las "ideas de belleza de Estados Unidos", ya que, aunque carecía de "encantadoras pieles y complexiones sonrosadas", su "gracia natural conquista a cualquiera" (p. 52).

Las opiniones acerca de los mexicanos blancos tendían a ser halagadoras solo en lo físico. Al dictador criollo Antonio López de Santa Anna se le definió como "un caballero, bien parecido" y "melancólico" (Calderón de la Barca, 1843, vol. 1, p. 49). Semejante impresión causó el gobernador criollo de Nuevo México, Manuel Armijo, en el periodista y explorador de mercados estadounidense George Wilkins Kendall (1847, vol. 1), quien subrayó que el gobernador medía "más de seis pies", con un cuerpo "sólido y bien construido" y era "ciertamente uno de los hombres mejor parecidos" (p. 315). Los viajeros anglosajones comprendieron pronto que la presencia de población indígena o blanca variaba por regiones. Consciente del predominio de sangre blanca en Guadalajara, Thompson (1846) consideró a la ciudad "la más fina de México, con más inteligencia [...] [y] una mejor población” (p. 85).

Como ocurrió con las indígenas, las mujeres blancas fueron el ejemplo favorito de los viajeros para describir a los criollos. Kendall (1847, vol. 1) quedó impresionado por la belleza de la mujer del norte de México, con nula o escasa infusión de sangre indígena. Al contemplar a una joven pobre "con una calabaza en su cabeza", en un camino lodoso y olvidado, lamentó que una mujer "tan blanca hubiera sido arrojada a semejante lugar" (p. 385). Los cronistas enfatizaron que, en ciudades ubicadas en zonas indígenas o mestizas, como Xalapa, había núcleos de población blanca en los que se "preservaba algo [...] de la sangre azul de la Vieja Castilla", lo que permitía que las mujeres fueran "deslumbrantemente blancas" (Ruxton, 1847, p. 26). Para explicar al lector anglosajón cómo 
eran los criollos de México, se les comparaba con la población de origen francés de Luisiana (Kendall, 1847, vol. 1, p. 321).

Nada resultaba más abominable que los mestizos. El rechazo hacia ellos se inspiraba en la inexorable condena anglosajona hacia la mezcla de razas. Lo primero que alteró al futuro vicegobernador inglés en tierras australianas Charles Joseph Latrobe (1836) al desembarcar en Tampico, fue la población que definió como "la más mezclada que se pueda concebir" (p. 24). Los cronistas describían una creciente fealdad a medida que la mezcla era más compleja. No existía algo más "horriblemente repugnante" que los "zambos", efecto de la unión de negro e indio: eran tan "oscuros" como los negros, pero sin sus "peculiaridades" positivas (Thompson, 1846, p. 188). Se consideraba a los "zambos", conocidos en México como lobos, "los más espantosos seres humanos que pueden verse" (Calderón de la Barca, 1843, vol. 2, p. 164).

$\mathrm{El}$ juicio sobre el físico de la mujer mestiza fue menos tajante que el que se tuvo con el hombre. Impactó a los observadores la facilidad con la que engordaba. Perdía la cintura y acumulaba grasa en la espalda. Los viajeros suponían que el cambio en la dieta, aunado a la mezcla racial, había ocasionado que desarrollara la complexión rolliza española sin el cuerpo ágil de la indígena. Educadamente, Albert Gilliam (1846), abogado de Virginia, nombrado cónsul en California, definió a las mestizas como "pletóricas" (p. 134). Menos cordial, Ruxton (1847) las consideró "gordas" (p. 46). Las mestizas tenían un elemento negativo adicional, atenuado en blancas e indígenas. Con la edad adquirían "la mayor apariencia de debilidad de cualquier país", combinada con "arrugas profundamente marcadas con los surcos de la vida" (Gilliam, 1846, p. 134). Esta cruda vejez se atribuía a la obesidad prematura. No obstante, algo positivo tenía la obesidad a temprana edad. Permitía que lucieran "voluptuosas", por lo que no había una "mujer realmente fea" (Ruxton, 1847, p. 46).

\section{Relaciones entre mexicanos}

Los viajeros anglosajones no ignoraban que, por su pasado colonial, los grupos raciales de la sociedad mexicana preservaban reglas no escritas de dominio y sumisión, pese a que las leyes anunciaban la igualdad jurídica de los ciudadanos. Observaban que las estructuras coloniales no solo persistían, sino que se habían reforzado. Esto era resultado de la violenta labor de los españoles, quienes debían "ser repudiados" por el "degradante estado de ignorancia y miseria al que han reducido a la población del país" (Beaufoy, 1828, p. 279). No había rincón en el que no se apreciara la labor destructora del orden colonial. Lejos de avergonzarse 
de sus actos, los criollos habían "preservado el más profundo desprecio hacia los pobres ultrajados indios" (Lyon, 1828, vol. 2, p. 231). Vista la fuerza de los militares y el poder de la Iglesia, los viajeros no podían "percibir un solo beneficio que los españoles hayan conferido a sus provincias americanas (Beaufoy, 1828, p. 281).

Cuando los anglosajones analizaban las relaciones raciales y de clase entre los mexicanos, sus conceptos sobre los indígenas cobraban un giro inesperado. Las crónicas sobre su inmensa "fealdad" y "estupidez" pasaban al olvido y en su lugar aparecía una profunda compasión por sus desgracias. Recordaban que en el pasado los indios habían demostrado ser inteligentes y que las circunstancias históricas los habían postrado. Dolía pensar que las monumentales obras prehispánicas habían sido diseñadas y construidas por la "gran raza que, cambiada, miserable y degradada, todavía camina sobre sus ruinas" (Stephens, 1843, vol. 1, p. 284). Para paliar los duros juicios sobre el carácter indígena, se remarcaba la enorme diferencia entre los "feroces bárbaros" que poblaban el norte del país y los "dulces indios del interior" (Calderón de la Barca, 1843, vol. 2, p. 308).

Los criollos no solo se aprovechaban de la ignorancia en que tenían sumidos a los indígenas. Lucraban con su carácter sumiso, que les impedía rebelarse. El control que ejercían sobre ellos se manifestaba en la horrenda pobreza en la que vivían. Su abatimiento hacía que "solo el cielo sepa de qué manera obtienen su sustento" (Gilliam, 1846, p. 68). Para expresar la condición que ocupaban los indígenas en las relaciones entre mexicanos, un cronista relató el adecuado ejemplo de una tarde tormentosa en la que "cruzar la calle habría sido impracticable para las damas y caballeros distinguidos, vestidos con medias y zapatos, de no haber sido por [...] los indios, sobre cuyas espaldas montaban sin escrúpulos para evitar mojarse" (Latrobe, 1836, p. 103).

Los sentimientos compasivos que surgían al observar la explotación de los indígenas daban pie a afirmaciones aventuradas, que contrastaban con los testimonios de los propios cronistas. En el afán de destruir el mito de la hidalguía de los criollos, el general y explorador procedente de Illinois, Thomas James (1916), quien recorrió el norte del país en 1822, afirmó que los indios "sobrepasaban por una cabeza a los españoles a su alrededor" y sus mujeres "extremadamente hermosas" y "con figura fina" eclipsaban a las poco agraciadas castellanas (p. 143). Algo similar ocurría con los mestizos, en especial con aquellos con fuerte carga indígena. Al contemplar su vulnerabilidad ante el escarnio criollo, el juicio del cronista cambiaba. Lyon (1828, vol. 2) los consideró "corteses, serviciales, alegres y perfectamente honestos" (p. 237). El mestizo, lo más "deleznable" de la sociedad mexicana, dejaba de serlo en oposición a los criollos. 
Por supuesto que los anglosajones advertían sus propias contradicciones. Entendían que el establecimiento del orden colonial habría sido imposible sin los excesos de España. Por ello tendieron a hacer una distinción entre la dura estructura social que la necesidad obligó a implantar siglos atrás y el perverso producto perpetuado por México. Pensaban que los indígenas de tiempos prehispánicos eran en extremo sanguinarios, por lo que el uso de la fuerza había sido inevitable. Como muestra citaban con frecuencia "la perfidia del pueblo y los sacerdotes de Cholula, quienes, tras dar la bienvenida a Cortés y los españoles, planearon exterminar a todos" (Calderón de la Barca, 1843, vol. 2, p. 98). En realidad, no culpaban a "los opresores españoles de estos indios" que impusieron "tres siglos del peor vasallaje colonial", sino la perpetuación del sistema en el México moderno (Thompson, 1846, p. 243). Aseguraban que la explotación se había recrudecido con la independencia, porque "si el español hizo poco por elevar el carácter del vasallo conquistado, el mexicano hace menos [...] por instruir a la piel más oscura a la que dice considerar en igualdad política" (Latrobe, 1836, pp. 25-26).

Un tema constante entre los viajeros era el hipócrita anuncio de que no había "distinciones políticas entre las varias castas de la población", cuando, por el contrario, las diferencias "eran muy marcadas" (Thompson, 1846, p. 166). En el México independiente, la piel se había convertido en el pasaporte para el éxito social y económico. La diferencia con Estados Unidos era la ausencia de una frontera bien definida entre grupos raciales. El tono de piel de una persona estaba vinculado al grado de "parentesco con los europeos", lo que exacerbaba los complejos raciales, especialmente entre las mujeres que se maquillaban para preservar la blancura con el "cuidado que tienen en su arreglo" (Gilliam, 1846, p. 134). El culto a la blancura engalanaba a quien no merecía ser bello. Se citaba el caso de la célebre Güera Rodríguez, cuyo recuerdo inspiraba a las mujeres mexicanas. Sin embargo, su único mérito para haber sido "suprema en México" era "su cabello claro" (Kendall, 1847, vol. 2, p. 393).

$\mathrm{El}$ tono de la piel abrumaba a los mexicanos. Dada la magnitud del mestizaje, no estaban seguros de su ubicación racial en la lucha por ser blancos. No era una preocupación menor, cuando bastaba observar la "complexión oscura" para definir el nivel de "perfidia" de una persona (James, 1916, p. 47). El enorme peso que la piel tenía en las relaciones sociales se constataba en todo, desde la vida política hasta el éxito amoroso. En el palacio presidencial era "muy raro observar una dama cuyo color indique una impureza de sangre". Lo mismo podía decirse "en gran medida, de los caballeros", aunque entre ellos había "excepciones" (Thompson, 1846, p. 166). Para abrirse paso al corazón de una mujer, es- 
pecialmente con propósitos de ascenso social, la piel blanca era la llave idónea. Nadie ignoraba que el hombre blanco "es siempre el favorito del sexo débil" (Ruxton, 1847, p. 43).

Los observadores anglosajones no estaban desprovistos de genialidad. Advirtieron que el culto a la blancura en el México independiente había dado origen a una casta no oficial e imprecisa, reconocida por todos, desde los indios en los mercados hasta las élites de palacete. La palabra que la definía no era ofensiva: en el México "igualitario" "todos los hombres de pelo claro son llamados güeros" (Kendall, 1847, vol. 2, p. 393). Con certeza, un cronista subrayó que no era el pelo, sino las "complexiones", lo que determinaba quién era "güero, güera" (Ruxton, 1847, p. 43). La importancia del nivel de blancura en las relaciones sociales entre los mexicanos, expresado en el concepto de "güero", permitió a los cronistas regodearse con bromas. Dado el atractivo que ejercían los más güeros, los anglosajones ansiaban haber frecuentado "mujeres en lugar de hombres" (Kendall, 1847, vol. 1, p. 321).

Algunos viajeros especulaban que las relaciones coloniales de sumisión continuarían exacerbándose con el paso del tiempo. Constataban que todo en la estructura sociopolítica mexicana anunciaba semejante derrotero, pues las fuerzas reformistas eran débiles. Bajo su visión, las injustas relaciones sociales se construían desde la base y esto se advertía en el hecho de que los pueblos indígenas estaban "gobernados por el sacerdote, quien [...] en todas partes, es un mestizo" (Latrobe, 1836, p. 55). Los mestizos a su vez eran dominados por los blancos. De esta manera se perpetuaba el vetusto sistema de castas. Sin embargo, otros cronistas creían que con educación, indígenas y mestizos lograrían prosperar y la estructura colonial finalmente colapsaría. Como ejemplos presentaban los casos de "un joven indio, de distinguidas habilidades, quien es miembro de la Corte Suprema de Durango" y de Vicente Guerrero, quien pese a ser "zambo", con "una fuerte mezcla de sangre africana en sus venas", estaba a un paso de convertirse presidente (Ward, 1829, pp. 26-27).

\section{Comportamiento/personalidad}

de los mexicanos por grupos raciales

Nada fascinó más a los visitantes anglosajones que describir las facetas destacadas del comportamiento y la personalidad de los mexicanos. Dada la complejidad racial, prácticamente todos concluyeron que era difícil, más no imposible, establecer pautas de comportamiento aplicables a todos los segmentos de la sociedad. Es decir, indígenas, blancos y mestizos, más las combinaciones entre ellos, daban vida a personalidades 
contrastantes y a patrones recurrentes. Su temperamento, sus miedos, sus preocupaciones o su humor se expresaban de diferentes maneras, pero también perfilaban un ethos nacional.

Una vez más, como ente exótico, fueron los indígenas quienes recibieron la mayor atención. Su personalidad era una incógnita. Los anglosajones advertían una duplicidad de carácter jamás atestiguada en otros pueblos. Por ello la palabra "ladino", cunning, fue su favorita para definirlos. Se aseguraba que eran "amigables y afables" y que poseían "el más agradable carácter y una gran amabilidad natural", por lo que era imposible que externaran "un gesto vulgar o incluso una grosería" (Poinsett, 1825, p. 266). Con su "mansa disposición, y la nativa sinceridad de sus gestos", el indígena personificaba al "ser más amigable de la especie humana" (Gilliam, 1846, p. 157). Los indios en su medio natural se mostraban más "amistosos" que los "mexicanos", o sea, que los "indios españoles" o indios aculturados (James, 1916, pp. 171-172). Como seres "sumisos" y "apacibles" no se involucraban en un solo "altercado entre ellos que parezca una pelea" (Poinsett, 1825, p. 108). Sin embargo, tras la careta de amabilidad y mansedumbre asechaba su verdadero carácter, considerado abominable.

Varios fueron los cronistas que relataron la inesperada transformación que se presentaba entre los indígenas cuando, desinhibidos, patentizaban su frustración. Bastaba que estos hombres pacíficos y gregarios se "inflamaran con licor" para tornarse "violentos, sanguinarios y vengativos" (Lyon, 1828, vol. 1, p. 259). "Cuando estaban borrachos" resultaban "ingobernables, salvajes y brutales al extremo"; en cambio "sobrios" eran "humildes con sus superiores, sumisos y dóciles" (Poinsett, 1825, p. 266). Una vez que se adentraban "libremente en el pulque" hasta los indígenas más responsables y confiables se transfiguraban en "mozos flojos" (Ruxton, 1847, p. 60). La duplicidad en el comportamiento de los indígenas revelaba que tras esa "estúpida apatía" con la que miraban a otros hombres, "escondían una enorme astucia" (Calderón de la Barca, 1843, vol. 2, p. 157). El hecho de que algo tan simple como el alcohol lograra una transformación radical demostraba que los indígenas eran "traicioneros, ladinos, indolentes [...] y cobardes por naturaleza" (Ruxton, 1847, p. 105).

Los anglosajones consideraban que urgía controlar el consumo de alcohol entre la población nativa, pues el pulque hacía estragos. Tal parecía que de manera "religiosa" los indígenas se habían propuesto "nunca estar sobrios cuando tienen la oportunidad de estar borrachos" (Beaufoy, 1828, p. 127). Este hecho, más su condición de explotados, forjaba seres viles, que exteriorizaban su degradación en su comportamiento. Se ha- 
bían convertido en "mentirosos por naturaleza, traicioneros y desleales con sus amigos y cobardes [...] con sus enemigos", y en ellos prevalecía la "duplicidad y la traición", combinada con una "indiferencia absoluta a las leyes morales" que se constataba en un "desvergonzado concubinato universal" (Ruxton, 1847, pp. 191-192). Con exageración, se aseguraba que eran tan primitivos que una de sus actividades favoritas consistía en "matar bichos en el cabello del otro" con una "infinita habilidad" y procuraban "matar solo un cierto número diariamente para que nunca terminara la diversión" (Beaufoy, 1828, pp. 243-244). El indio no mostraba el menor interés por prosperar y solo "cultivaba lo suficiente para la subsistencia de su familia" (Ruxton, 1847, p. 23).

El comportamiento de los indígenas significaba una carga monumental para México. Su violenta volubilidad se constataba hasta en el sexo débil. De forma repentina, las amables mujeres caían en el "vicio común" de la violencia, que se expresaba en su "extraordinaria inclinación" a "discutir y pelear" "con piedras y cuchillos en sus puños, y niños a sus espaldas" (Penny, 1828, pp. 64-65). Ni el gobierno nacional confiaba en el indígena para las grandes tareas nacionales, algo que se advertía en los soldados rasos del ejército. Eran "malos en serio" y "más difíciles de controlar que cualquier otra raza de hombres en existencia" (Ward, 1829, p. 233). ¿Cómo podía México lidiar con seres volubles, violentos, alcohólicos y culturalmente degradados? La respuesta se encontraba en la gran carencia del indígena. No contaba con el indómito orgullo que caracterizaba al indio estadounidense (Thompson, 1846, p. 166). Si el orgullo del indígena mexicano hubiera sido mayor, su combinación con su latente naturaleza violenta habría dado origen a un país inmanejable.

Los viajeros tendían a coincidir que el mayor atributo de los indígenas descansaba en su inclinación al trabajo. Laboraban arduamente en las peores condiciones y, por carecer de orgullo, no se quejaban. Sus cualidades como "población útil" los hacían "muy superiores a sus amos españoles", quienes vivían en la indolencia (James, 1916, p. 139). Las compañías mineras anglosajonas de Guanajuato advertían que, a pesar de su condición "precaria" y "casi salvaje existencia", cuando tenían oportunidades laborales los indígenas de inmediato se entregaban al "trabajo activo" (Ward, 1829, p. 469). El esfuerzo que colocaban en mejorar sus condiciones de vida por medio del trabajo se constataba en las grandes ciudades, en cuyos alrededores pululaban las "chozas" "construidas de lodo (adobe)" por indígenas que abandonaban el campo. Por desgracia, el carácter violento del indígena en su versión urbanizada ocasionaba que semejantes barrios estuvieran "habitados por tribus de villanos" (Penny, 1828, p. 45). Esto no borraba su laboriosidad, que los 
animaba a entregarse "gustosamente a una semana de trabajo" (Ward, 1829, p. 468).

En el extremo opuesto de los indígenas se encontraban los mestizos, considerados por los cronistas como los mexicanos más orgullosos. Este orgullo surgía de la magnitud de sus complejos. En su conducta exponían "la holgazanería del indio combinada con la superior perfidia del blanco", por lo tanto, se especializaban en el "engaño" y en "todo tipo de robo" (Penny, 1828, p. 65). El mestizo, sin una condición racial bien definida, estaba atormentado por demonios psicológicos. Mientras los indios ocultaban una agresividad que solo afloraba con el alcohol, el mestizo se deleitaba en mostrarse pendenciero, como expresión de su falso orgullo. Este comportamiento lo convertía en el mexicano más "perverso, ignorante y bárbaro" (Ward, 1829, p. 52). Sin embargo, no había que asustarse ante su agresividad, que era tan aparente como su jactancia. El mestizo se parecía al "inusual número de perros" que vivían en las ciudades mexicanas: el visitante "pronto se da cuenta que desahogan su coraje en ladridos -rara vez muerden" (Kendall, 1847, p. 45).

El falso orgullo no era la peor peculiaridad del mestizo, sino su notoria aversión al trabajo. Al igual que el español, había adquirido una afición a divertirse, que no compensaba con educación. Del indígena no había heredado la laboriosidad, puesto que pensaba que el trabajo hacía aflorar su faceta de indio, de la que deseaba escapar. Su holgazanería se alimentaba por "la abundancia de la naturaleza y sus escasas necesidades, combinadas con el clima caluroso". Con el pretexto de "escapar del sol" se entregaba a la apatía (Gilliam, 1846, p. 125). En las regiones marcadamente mestizas se constataba la presencia de "gente medio adormilada" que "consumía la mitad del día" en la "siesta". El viajero recalcaba que "para esta raza floja incluso hablar representa un esfuerzo" (Lyon, 1828, vol. 1, p. 64). Cuando la necesidad obligaba a los mestizos a trabajar, con mañas evadían sus labores. Esto se constataba entre la "insolente" servidumbre urbana, que patentizaba su "adicción a robar", combinada con "holgazanería, embriaguez, suciedad" y su amor al "placer de no hacer nada" (Calderón de la Barca, 1843, vol. 1, pp. 282-283). Bromeando, un cronista afirmó que "la rapidez de mis movimientos asombra a los flojos mestizos" (Poinsett, 1825, p. 36).

Tampoco el comportamiento de la población blanca escapaba del juicio implacable de los anglosajones. La buena impresión física que por lo general les causaba se evaporaba cuando afloraba su conducta. Salvo contadas excepciones, los criollos despuntaban como una "raza indolente, déspota y arrogante" (Lyon, 1828, vol. 1, p. 231). Creían ser una extensión del Viejo Mundo y se preciaban de su buen gusto en todo, desde 
el vestir hasta los vinos. No obstante, eran el remanente de una élite colonial, degradada por su posición periférica. El promotor comercial, arqueólogo y diplomático estadounidense John Lloyd Stephens (1843), a quien se acredita el redescubrimiento de la civilización maya, argumentó que el mundo colonial había envilecido a los criollos, algo que se notaba en "la extraordinaria ignorancia de toda la gente, indios y blancos" ( $\mathrm{p}$. 383). Su bajo nivel cultural se percibía en que jamás se encontraría "un libro en las manos de un caballero mexicano" (Beaufoy, 1828, p. 126). Por consiguiente, entre los criollos "la educación se encontraba en el nivel más bajo" (Penny, 1828, p. 45).

Había quienes, con elogios a la belleza de México, comprendían la incultura del criollo y justificaban su desinterés por la lectura. Resultaba imposible concentrarse y "hojear un libro cuando el cielo azul siempre sonríe en las ventanas abiertas" (Calderón de la Barca, 1843, vol. 1, p. 341). Los pretextos sobre la imposibilidad de leer ante tanta belleza no ocultaban un grave defecto de los criollos. Una cosa era no contar con una adecuada educación debido a su condición de élite periférica; otra, grave y condenable, presumir una cultura que no tenían. Como seres orgullosos, los criollos intentaban mantener "una reputación de sabiduría controlando la lengua", pero quien los trataba con regularidad advertía que "con muy pocas excepciones, carecían totalmente de educación" (Beaufoy, 1828, p. 126).

La mujer criolla personificaba como nadie la baja educación de los blancos. Procuraba contraer matrimonio con un hombre de buena posición y después llenarse de hijos, algo que se apreciaba hasta en las mujeres más encumbradas, incluida una "condesa" que "parecía ser muy joven". Con seis niños a su lado, confesó que, "entre los ricos y prominentes, los matrimonios a temprana edad eran comunes" y "no era raro que las niñas se casaran a los trece años" (Poinsett, 1825, p. 77). Las criollas no se interesaban por la lectura, a pesar de contar con tiempo de sobra para hacerlo (Thompson, 1846, p. 162). Como personas "totalmente incultas", habían adquirido "conciencia de su inferioridad", por lo que en reuniones sociales eran "tímidas y reservadas" (Ruxton, 1847, p. 46). Su carencia de cultura las hacía inútiles. Como consecuencia, los hombres blancos, con su prepotencia natural, "no tenían el menor respeto por las mujeres" y, a la vez, "las mujeres no se respetaban así mismas" (Beaufoy, 1828, p. 131). Humilladas por sus esposos y sometidas por la estricta moral católica eran hipócritas como pocas. En cuanto tenían la oportunidad se vengaban de sus dictatoriales esposos mediante "la tentación de la oportunidad" (Thompson, 1846, p. 162). 
Si bien los cronistas anglosajones esquematizaron las personalidades de los diferentes grupos raciales, también desentrañaron algunas peculiaridades aplicables a todos los mexicanos. De forma sorprendente, todos ellos encontraron tres características omnipresentes, que superaban las barreras entre indígenas, mestizos y blancos. Las tres eran negativas. La primera fue el carácter corrupto de los mexicanos, independientemente de su condición sociocultural. El viajero descubría cómo todo en México se aceitaba con dinero, desde el cumplimiento de las labores obligatorias de los funcionarios públicos hasta el trato dispensado por los caciques que controlaban a las comunidades indígenas, pasando por el recibimiento en las tertulias de la alta sociedad. En pocas palabras, "el estado de este país" permitía concluir que "funcionaba con soborno y corrupción" (Gilliam, 1846, p. 168).

La cultura de la corrupción se había enraizado con tal fuerza que, lejos de condenarse, se consideraba una vía óptima y legítima para alcanzar objetivos. Incluso la gente que se autodenominaba "respetable" había perdido la noción de lo que era adecuado y exhibía "morales perversas" (Penny, 1828, p. 45). Quien procedía con ética recibía el escarnio de sus semejantes, quienes lo consideraban ingenuo. Se había llegado al extremo de considerar al juego como algo honorable, pues quien lograba "establecerse" como un hombre que hacía dinero fácil "ascendía en lugar de declinar en la estimación pública" (Gilliam, 1846, p. 126). Esta admiración por quienes se enriquecían mediante el juego, el soborno o el contubernio era ya un "mal nacional" (Ruxton, 1847, p. 31).

La corrupción permeaba todo. Se advertía entre indígenas y criollos o en grandes urbes y pueblos. Ni una pequeña población tan alejada del centro político como Santa Fe, Nuevo México, podía escapar de la podredumbre que infectaba a todos los grupos sociales. Allí, el gobernador criollo Armijo, elogiado por su imponente físico, había demostrado ser un hombre "totalmente carente de todo principio moral" (Kendall, 1847, vol. 1, p. 315). Un viajero, acostumbrado al capital social presente en los pueblos anglosajones, confesó que jamás había visto "una sociedad tan aniquilada" moralmente como la que encontró en "todas las clases sociales en Santa Fe". La voracidad de los funcionarios de Nuevo México aunada a la complicidad de la gente lo llevó a precisar que "había visto suficiente de la sociedad mexicana para estar totalmente asqueado de ella" (James, 1916, p. 139).

La personalidad corrupta de los mexicanos se apreciaba en toda su magnitud en la burocracia, que mostraba una rapacidad desenfrenada. Con las leyes en mano, los funcionarios colocaban todo tipo de obstáculos 
para obtener sobornos. Ni los extranjeros, supuestamente amparados por sus diplomáticos, escapaban de los "voraces" agentes aduanales que les daban la bienvenida al país con la avidez de "colocar sus violentas manos" sobre la mercancía y quedarse con ella (Gilliam, 1846, p. 49). Dado que los ciudadanos habían aceptado convivir con la corrupción, muchos de ellos, lejos de indignarse con la burocracia, se hacían cómplices. Los extranjeros denunciaban a "todas las clases de hombres, mujeres y niños" que, manipulados por los funcionarios, intentaban apropiarse de sus mercancías y no cesaban en su esfuerzo hasta que se les sobornaba, con lo que se "lograban maravillas" (Lyon, 1826, vol. 1, pp. 3-4). Esta corrupta connivencia entre pueblo y gobierno había ocasionado que "el fraude y la deshonestidad" fuesen "tan prevalentes" que se había perdido "la apropiada concepción de cómo discriminar lo que era justo de lo que no lo era" (Gilliam, 1846, p. 274).

La explicación anglosajona sobre el carácter deshonesto de los mexicanos se fundaba en la historia. Los cronistas afirmaban que España había hecho corrupto "no solo a México, sino a todos los países españoles" (Thompson, 1846, p. 80). Juzgaban que la fuerza del pasado era tal que la corrupción se había institucionalizado, con lo que se había perdido la esperanza de combatirla. Los mexicanos eran un "pueblo desmoralizado", que acosado por los obstáculos burocráticos y sociales "prefería otros medios de subsistencia que el trabajo honesto" (Ruxton, 1847, p. 30). Esta desesperanza era comprensible, pues los políticos siempre prometían que acabarían con la corrupción y terminaban siendo peores que sus antecesores. El caso crónico se encontraba en Santa Anna, quien tuvo la oportunidad de "esmerarse con vigor", "emular el ejemplo de Washington" y así ganar la "espléndida inmortalidad" (Mayer, 1847, pp. 351-352). Sin embargo, terminó siendo una expresión de los males mexicanos al mostrar que su "gran vicio es la codicia y ha sido víctima de ella" (Thompson, 1846, p. 80).

La corrupción estaba detrás de varios de los grandes males mexicanos. El más lamentable, según los cronistas, era la inseguridad. La complicidad entre autoridades corruptas y delincuentes hacía imposible atacar el problema de raíz. Se constataba la fragilidad de la vida y de la propiedad, en especial en los caminos, asolados por bandidos. Detrás de cada banda criminal había funcionarios o políticos que la apoyaban, en lo que ya se había convertido un "sistema perfecto" (Kendall, 1847, vol. 2, p. 371). Por lo tanto, la "pestilencia de ladrones que infesta la república no había sido erradicada" ni lo sería (Calderón de la Barca, 1843, vol. 2, p. 115). Quien deseara transitar por México debía contar con "pistolas de doble cañón y revólveres" y estar "constantemente preparado para el ataque". De no hacerlo, terminaría siendo una cruz más de las numerosas que "marcan el lugar donde hubo una muerte violenta" (Mayer, 1847, pp. 19-20, 169). La 
corrupción facilitaba la labor de los criminales, al garantizar impunidad, que representaba la raíz del problema (Kendall, 1847, vol. 2, pp. 371-372). Mientras esta continuara, el país seguiría cubriéndose con "historias de sangre y asesinato" (Calderón de la Barca, 1843, vol. 2, p. 114).

Los anglosajones, incluidos los católicos, aseveraban que, además del gobierno, el otro corruptor de los mexicanos era la Iglesia católica. La personalidad corrupta del mexicano se entendía por la magnitud del control ejercido por esta institución jerárquica y anquilosada. No obstante, su condición de corruptora palidecía ante su papel fundamental como forjadora del segundo gran rasgo universal de la conducta de los mexicanos: su naturaleza supersticiosa. Los cronistas aseveraban que no existía "país en Europa o América donde las formas supersticiosas de culto se observen de manera más estricta que en México" (Poinsett, 1825, p. 117). Ni entre las naciones mediterráneas europeas, intolerantes por tradición, se había alcanzado el nivel de cerrazón existente en México. Se aseveraba que el "catolicismo romano de Europa" era "más ligero, comparado con el establecido en este país y practicado por sus habitantes" (Latrobe, 1836, p. 125).

Los fundamentos de la personalidad fanática y supersticiosa yacían, según los cronistas, en la nefasta unión de las creencias prehispánicas con el catolicismo. Los indios no habían escapado totalmente de su "idolatría" y la preservaban mediante la combinación de la "superstición de su antiguo culto con los ritos de la iglesia católica" (Poinsett, 1825, p. 117). Mediante el sincretismo, "las ceremonias supersticiosas de los habitantes originales" sobrevivían disfrazadas en la "mezcla de ceremonias dañinas y grotescas" (Kendall, 1847, vol. 2, p. 182). Este sincretismo se constataba por doquier. Un viajero observó a tres mujeres "bailando seriamente ante la imagen de un santo, quien es glorificado por sus curas milagrosas de fríos y calenturas" (Lyon, 1826, vol. 2, p. 25). Otro mencionó cómo "el repicar de una pequeña campana" que "anunciaba el paso de la hostia", bastaba para que "todo quedara quieto" y los "tenderos y sus clientes, los léperos y los niños ruidosos, se despojaran de sus sombreros y se arrodillaran en el pavimento", "persignándose de forma devota" (Poinsett, 1825, p. 105).

La facilidad con la que la Iglesia determinaba el comportamiento de los mexicanos se fundaba en "la influencia y el poder ejercidos por los sacerdotes" "sobre una población ignorante y supersticiosa" (Kendall, 1847, vol. 2, p. 343). La sociedad era víctima de "la mano de la superstición", combinada con "la ambición de demagogos" (Gilliam, 1846, p. IV). Bastaba sumergirse un poco en las entrañas de la Iglesia para atestiguar la manera cómo dichos demagogos moldeaban el carácter de los mexicanos para obtener provecho. En un México pobre y con enormes carencias, "el confort" se había "refugiado con el arzobispo" (Calderón de la Barca, 1843, vol. 1, 
p. 337). La Iglesia no solo expoliaba a los supersticiosos mexicanos, sino que patentizaba un escaso apego a sus propias enseñanzas moralizantes. Se sabía que "los buenos padres [...] tienen sus compañeras" (Kendall, 1847, vol. 2, p. 342). Con sorna, un cronista mencionaba a los "sobrinos" y "sobrinas" que vivían en las parroquias con los sacerdotes, quienes, además, eran más afortunados que el resto de los hombres, pues "se permitían en lujo de cambiar a sus amigas femeninas" (Beaufoy, 1828, p. 155).

La tercera gran particularidad en el comportamiento de los mexicanos era su marcada xenofobia. El nacionalismo institucionalizado no había cobrado fuerza, pero los extranjeros ya advertían una sociedad desconfiada del exterior. Aseguraban no haber visto un país en el que sus habitantes se ofendieran con tanta facilidad ante la crítica externa o que mostraran tanto recelo con respecto de las intenciones de los visitantes. La xenofobia había echado hondas raíces en todas las clases sociales y grupos raciales. Un viajero aseguró que existía un marcado "espíritu de aborrecimiento hacia nuestras personas", evidente en las actitudes defensivas de los mexicanos, quienes siempre culpaban a los extranjeros de todo lo que ocurría sin profundizar en mayores explicaciones (Latrobe, 1836, p. 198). El sentimiento de asilamiento en que caían los extranjeros al viajar por México era tal que un cronista británico mencionó la felicidad que experimentó al encontrarse con un "hombre blanco, un hombre que hablaba bien nuestra lengua, un ciudadano de los Estados Unidos de América" entre tantos mexicanos que "se niegan a llamarnos cristianos" (Penny, 1828, p. 148).

El mexicano tenía una conducta predecible para justificar sus errores. Tendía a imputar las desgracias nacionales a los extranjeros, a quienes no les perdonaban ni faltas menores. Como prueba de esto, un británico mencionó el caso de un "pobre estadounidense que fue acuchillado" y su "tienda saqueada" por no haberse arrodillado ante el paso de una procesión (Beaufoy, 1828, pp. 141-142). El visitante debía ser muy cuidadoso en su interacción con los "estratos más bajos" de la sociedad, entre los cuales la xenofobia adquiría su mayor virulencia y la "hostilidad hacia los extranjeros" era palpable (Kendall, 1847, vol. 2, p. 135). Por supuesto que los cronistas exageraban en la magnitud del odio y la desconfianza de los mexicanos hacia todo lo proveniente del exterior. Prueba de ello era la supuesta "inquietud" con la que "observarían a un europeo cuando se bañaba o se mudaba la ropa", pues creían que "tenía cola como castigo a su maldad" (Beaufoy, 1828, p. 147).

Los cronistas se esforzaron por explicar una xenofobia desenfrenada que no habían advertido ni en la atrasada Birmania británica. Tal vez era producto de la magnitud de la mezcla racial, que había creado una enorme población mestiza con aspiraciones, molesta porque el comercio "es- 
taba principalmente en las manos de extranjeros" (Latrobe, 1836, p. 24). Otros suponían que el origen de la xenofobia era el intento de los líderes mexicanos por forjar un nacionalismo vibrante mediante la manipulación política, algo que se había recrudecido a raíz de la guerra de independencia. Unos cuantos meses después de que México se librara del yugo español, un cronista sentenció que la magnitud del desprecio recibido le permitía concluir que todos los mexicanos eran "sinvergüenzas" (James, 1916, p. 155). Algunos observadores coincidieron en que los grupos políticos "habían llevado la envidia y el odio hacia los extranjeros a un nivel ridículo" (Latrobe, 1836, p. 117). En un futuro esto le haría mucho daño a México, ya que lo consolidaría como un país cerrado y desconfiado.

\section{Mediante la influencia anglosajona,} los mexicanos lograrán redimirse

Las opiniones anglosajonas sobre los mexicanos tendieron a ser mordaces. No obstante, los cronistas no carecieron de constantes contradicciones que demostraban una doble intención en su discurso. Denigraban a los mexicanos y después resaltaban sus atributos y capacidades no aprovechadas. Las opiniones positivas sobre los mexicanos no fueron unánimes ni tajantes como las negativas, pero aparecieron con frecuencia. Esta visión dual de los cronistas tenía un claro propósito, advertido de forma recurrente en sus textos. Pretendían demostrar que el largo dominio absolutista español había gangrenado a México. Los mexicanos eran meras víctimas de las circunstancias históricas y podían redimirse, no con el absolutismo de la Santa Alianza, sino mediante la acción liberadora de la gran hermandad anglosajona.

Los viajeros remarcaban que las particularidades negativas de los mexicanos no eran producto de un determinismo racial, sino de abominaciones socioculturales. Condenaban comportamientos como "escupir, fumar y eructar, considerados atributos indispensables entre las damas y los caballeros" (Beaufoy, 1828, p. 130). Detestaban las fiestas populares heredadas de las culturas prehispánicas y española, en las que se "bailaba con los más disolutos y depravados" (Thompson, 1846, p. 135). Aborrecían la "prevalencia del juego" en "las afecciones de la gente", un resultado obvio del largo dominio de España (Gilliam, 1846, p. 125). Reprobaban la supuesta costumbre matrimonial de permitir las borracheras de la pareja, siempre y cuando no se embriagaran ambos al mismo tiempo para que regresaran sanos a casa (Lyon, 1826, vol. 2, p. 132). Pintaban un país en "indolencia, tanto física como moral", resultado de las circunstancias, más no de la raza (Calderón de la Barca, 1843, vol. 1, p. 341). Es decir, 
los mexicanos eran una "raza extraordinaria" a la que la historia había castigado de forma injusta (Lyon, 1826, vol. 2, p. 231).

El hecho de que los anglosajones juzgaran, con evidente racismo, algunas de las particularidades físicas de los mexicanos no los hizo deterministas raciales. Solo un chauvinista negaría que, en ciertos pasajes de sus textos, estaban en lo correcto. Por supuesto que los indígenas tenían piel oscura, labios gruesos, ojo inclinado y rasgos mongoles, o que, al igual que los mestizos, tendían a ser pequeños, débiles, enfermizos, con piel y pelo maltratados. Siglos de desnutrición eran inocultables. En México, en cambio, se cantaban loas hipócritas a la legendaria fortaleza de la "raza" indígena. Los anglosajones no eran deterministas raciales porque atribuían los problemas mexicanos a un condicionamiento sociocultural prehispánico y español. Incluso cuando no controlaban su inherente racismo, procuraban aplacarlo. Uno de ellos afirmó que "las damas de México" no eran "guapas [...] pero tampoco feas" y, pese a sus deficiencias físicas, tenían "los grandes atributos del corazón, la afección, la amabilidad y la benevolencia en todas sus formas" (Thompson, 1846, p. 161). Esas mismas mujeres no desplegaban su inteligencia, no porque carecieran de ella, sino porque se les "mantenía bárbaramente en un estado de perfecta ignorancia" (Lyon, 1828, vol. 1, p. 148).

Hubo reiterados comentarios elogiosos sobre los atributos presentes en los mexicanos, que siglos y hasta milenios de represión no habían logrado erradicar. Los arrieros, vilipendiados por su afición al pulque, denotaban la verdadera esencia de la personalidad mexicana. Pese a la terrible pobreza en que vivían, transportaban "la más valiosa mercancía y metales preciosos" con una admirable probidad y como eran "una muy grande proporción de la población", se infería que esta tendía a la "devota honestidad, puntualidad, paciente resistencia y hábil ejecución del deber" (Mayer, 1847, p. 18). La corrupción colonial española no había aplacado la honestidad de un pueblo trabajador, que solo requería de mejores condiciones para mostrar lo mejor de sí. Hasta los pordioseros manifestaban un gigantesco potencial entumecido por las circunstancias socioeconómicas. Alguien los consideró una "clase industriosa" que se levantaba temprano y que mendigaba "incluso antes de que el sol hiciera su aparición" (Kendall, 1847, vol. 2, p. 327).

Los anglosajones concluyeron, de forma unánime, que de todos los atributos de los mexicanos el más maravilloso era su amabilidad. Esta particularidad superaba todas las barreras sociales y raciales. Los propios escritores que detectaban una inmensa xenofobia resaltaban la capacidad de los mexicanos para sosegarla cuando recibían a un visitante. Confirmaban que la desconfianza hacia los extranjeros no impedía que se 
les tratara con cortesía. En más de una ocasión, un cronista que maldecía la xenofobia mencionó lo "extremadamente amistosos, hospitalarios y amables" que eran sus anfitriones, por lo que se separaba de "ellos con tristeza" (Poinsett, 1825, p. 224). Los indios se esmeraban por agasajar a sus visitantes, aunque fuera con "carne cocinada bajo piedras", un platillo "horrible" que "olía y sabía a humo" (Calderón de la Barca, vol. 2, p. 21). Por su parte, los criollos eran "apacibles y corteses en sus procederes" y "hospitalarios con los extraños" (Poinsett, 1825, pp. 159-160). Aun en poblaciones conocidas por su repudio a los extranjeros, un viajero se asombró porque "no se nos profirió un insulto por ningún individuo" (Kendall, 1847, vol. 2, p. 135). Esta amabilidad se constataba por doquier. Los propios mexicanos "nunca se saludan sin abrazarse", un gesto que, combinado con otras muestras de cortesía, permitía definirlos como "la gente más amable [...] en el mundo" (Mayer, 1847, pp. 50, 52).

Ni la labor destructora de la Iglesia católica, controladora de mentes y voluntades mediante el miedo a dios, había conseguido borrar las virtudes de los mexicanos, quienes incluso intentaban reformarla. A diferencia de los "curas" españoles, los mexicanos eran "consejeros, amigos y protectores de sus rebaños". El cronista que advirtió esto conjeturó que la consolidación de los sacerdotes como "agentes de caridad y ministros de la misericordia" se presentaba en el contexto de la "República", en clara alusión al gradual rompimiento con el orden monárquico español (Mayer, 1847, p. 328). La generosidad del pueblo permitía una sana interpretación de "la religión de Roma", basada en tal "benevolencia" que al mendigo "rara vez o nunca se le rechaza de la puerta del rico" (Kendall, 1847, vol. 2, p. 341). La inmensa voluntad de los mexicanos por desplegar sus atributos frente a una institución corruptora convenció a un viajero de la imperiosa necesidad de acabar con iglesias y conventos para así "destruir tan asquerosa superstición" y "rescatar a esta pobre sufriente humanidad de tan horrible degradación" (Beaufoy, 1828, p. 157).

En el diario esfuerzo por romper con el pasado colonial se fundamentaba el argumento central, implícito o explícito, de todos los cronistas: el rescate de los mexicanos. Había salvación para ellos, puesto que sus problemas no eran raciales, sino producto de las instituciones que los habían ultrajado. Los anglosajones especulaban que "si a la raza de los mexicanos se le enseñara una justa aversión al fraude y al crimen" el país lograría redimirse por medio de las leyes (Gilliam, 1846, p. 157). Apreciaban la capacidad de la población para prosperar en un entorno socioeconómico totalmente adverso. Un cronista celebró el inmenso esfuerzo de "un ranchero muy inteligente" que, "aunque vivía miserablemente", logró, con prudencia casi anglosajona, ser propietario de decenas de re- 
ses y centenas de chivos (Penny, 1828, p. 197). Era la representación del mexicano emprendedor que clamaba por la destrucción de las estructuras prehispánicas y coloniales. A los más pobres; es decir, a los "desnutridos esclavos de la iglesia", se les auxiliaría con una reforma agraria que les demostraría las ventajas de la propiedad individual y así la "naciente civilización se extendería sobre la tierra" (Mayer, 1847 p. 351).

Por supuesto que la intención de las crónicas no podía ser más clara: la redención de los mexicanos se alcanzaría mediante una amplia reforma basada en el liberalismo anglosajón. Mientras el cambio no arribara, el potencial de los mexicanos se seguiría desperdiciando en el "cruel deporte" de las peleas de gallos, que no eran más que una "manera singularmente repugnante y poco interesante de matar el tiempo" (Beaufoy, 1828, pp. 244-245). La Constitución de 1824, recibida con falsas esperanzas, no había conseguido reformar al país por dos razones. La primera, porque había preservado a la religión católica como única y oficial, con lo que había "destruido el derecho de los hombres a pensar y actuar por sí mismos", y así había dado "a un sacerdocio corrupto el completo dominio espiritual sobre el pueblo" (Gilliam, 1846, p. 429). La segunda razón era práctica. Si bien dicha constitución contaba con numerosos elementos positivos "exactamente reproducidos de la de Estados Unidos", estos superaban el nivel educativo de los mexicanos (Thompson, 1846, p. 186). Para resolver este problema debía materializarse un mayor involucramiento anglosajón en México.

Según los cronistas, los anglosajones debían introducirse en el país con mayor energía y defenderlo de la amenaza de la reinstauración colonial encarnada por las potencias absolutistas de la Santa Alianza. En la Doctrina Monroe existía una justificación legal y moral para rescatar a los mexicanos. Había que complementarla con un decidido apoyo al "grupo político más educado", integrado por quienes ansiaban "introducir las políticas más ilustradas de Estados Unidos y Europa", y el cual, dada la xenofobia de la población, vivía en "la deshonra" (Latrobe, 1836, p. 117). Urgía extender su influencia entre "las mejores clases de los mexicanos", que son "tan patriotas como las de otros países" (Thompson, 1846, p. 247). Los anglosajones debían dejar de ser meros espectadores y actuar con mayor agresividad que la Santa Alianza. Con su influencia, el comercio, la industria y la agricultura florecerían. Un valle fértil, como el del río Bravo, que permanecía en el abandono, "alimentaría cinco veces la población que ahora contiene" (Kendall, 1847, vol. 1, p. 395). Para un impulsivo cronista británico, la población "nunca progresará o se civilizará" si no se integraban anglosajones a ella (Ruxton, 1847, p. 105).

México contaba con el material humano para mejorar. Las descripciones que los cronistas hicieron sobre los mexicanos evidenciaban que 
las inclementes críticas hacia ellos eran solo un magistral pretexto para destacar sus virtudes entumecidas por el orden colonial. El liberalismo anglosajón, sustentado en una clase media productora y consumidora, constituía el prerrequisito para rescatar esas virtudes. Por ello, los cronistas aseguraron que el futuro del país se encontraba en su clase media, que debía crecer y contar con mayor influencia. Dado que la clase alta "es siempre la más corrupta, tramposa y débil" y la baja la "más viciosa", en la "sobria, paciente, patriótica, trabajadora, educada, frugal" clase media residían "las verdaderas virtudes y los rasgos nobles" (Mayer, 1847, p. 49). Advertían que, gracias a los vientos de libertad que soplaban en México, hasta las élites borraban la herencia del prepotente absolutismo español. Empezaban a mostrar una cara "franca y cordial" y a deshacerse "de las declaraciones sin sentido que acostumbran los españoles" (Poinsett, 1825, p. 34). A medida que se desmantelaran las viejas estructuras socioculturales y económicas, retoñaría la "honesta y nada pretenciosa naturaleza del carácter" presente en los mejores mexicanos (Mayer, 1847, p. 49).

Se infería en las crónicas viajeras que la acción civilizadora anglosajona eliminaría los remanentes socioculturales prehispánicos y coloniales, desde la superstición y las corridas de toros hasta el vicio del juego, pasando por las danzas indias "perezosas y monótonas" (Calderón de la Barca, vol. 1, p. 252). También se acabaría la "detestable práctica de fumar" puro entre las mujeres, con lo que serían "muy agradables y amigables" (Poinsett, 1825, p. 160). La destrucción de los remanentes del sistema de castas colonial permitiría una mayor movilidad social e interacción entre los diversos grupos. Ya se advertía que esto sería posible en el México independiente, pues aparecían ejemplos en detalles insignificantes de la vida cotidiana. Hasta "las clases altas" habían adquirido la costumbre india de comer "con tortillas y chile" y "nunca terminan su desayuno, comida o cena sin ellos" (Penny, 1828, p. 123). Con relaciones socioculturales más abiertas se afianzarían la democracia y las libertades políticas.

Los cronistas reiteraban que la xenofobia y el orgullo, arraigados entre criollos y mestizos, hacían más daño al país que cualquier otra cosa. Los mexicanos tenían que realizar un esfuerzo titánico por librarse de ellos para alcanzar la redención. Debían deshacerse de ese nacionalismo extremo con el que se creaban una "idea extravagante de la riqueza y las capacidades de su país, al que imaginan más grande que cualquier otro" (Hardy, 1829, p. 436). La renuncia al orgullo y la xenofobia implicaba la bienvenida a la pragmática perspicacia anglosajona. Emboscadas como inocentes crónicas viajeras, las magníficas experiencias de los cronistas anglosajones que recorrieron México terminaron por transformarse en un llamado a impedir el retorno del absolutismo. De caer en el nocivo embru- 
jo de la Santa Alianza, los mexicanos reforzarían las estructuras del pasado, que habían inutilizado sus cualidades. En este sentido, los cronistas anglosajones resultaron ser excelsos maestros de la geopolítica.

\section{Conclusión}

Las exquisitas descripciones etnográficas sobre los mexicanos, combinadas con amenas anécdotas y magníficas referencias históricas, evidencian que los cronistas anglosajones que visitaron México durante el primer cuarto de siglo de vida del país nunca renunciaron a su excelsa tradición cronística. Al escribir tenían en mente a sus potenciales lectores. A fin de cuentas, el libro era el medio de difusión del conocimiento dominante en la primera mitad del siglo XIX. La penny press, prensa popular y amarillista que masificó el periodismo y desplazó al libro como fuente de información, todavía no ejercía su dominio. Es más, en Gran Bretaña aún era ilegal (Matthews, 2017, pp. 63-66). Uno de los pasos lógicos hacia la fama seguía siendo convertirse en un famoso escritor de libros.

Dada la centenaria calidad de la crónica anglosajona, la primera impresión del historiador, al estudiar a los viajeros que visitaron México, es atribuir una intención cultural-recreativa a sus escritos. Sin duda la hubo, pero los viajeros que escribieron las más influyentes crónicas tenían un propósito más profundo que la fama literaria. Eran diplomáticos, militares y hombres de negocios, con una clara visión geopolítica. Además de obtener fama como escritores, intentaban cumplir con éxito su función de animar a sus gobiernos a involucrarse en la redención de México. En la era de la Doctrina Monroe, no había estadounidense o británico culto que no temiera al restablecimiento del monarquismo conservador en Hispanoamérica. Como bien lo dijo uno de ellos, una vez que México había alcanzado su independencia "no hay poder sobre la tierra capaz de quitársela" (Niles, 1822, p. 8). Al sugerir el rescate anglosajón del país, los cronistas se vislumbraban como garantes de la causa de la "independencia" mexicana.

En las crónicas sobresalió una visión negativa sobre las particularidades físicas, relaciones sociales y personalidad/comportamiento de los mexicanos. Sin embargo, de manera sorprendente, en un mismo texto se aplacaba dicha visión con disquisiciones sobre el potencial de los mexicanos y sus características positivas. Aunque se trataba de una notoria contradicción, no era un error. Los cronistas anglosajones se cuidaron mucho de parecer deterministas raciales. Concentraron sus críticas en aspectos socioculturales y enaltecieron el carácter dormido de los mexicanos. En otras palabras, estos contaban con el potencial para redimirse. Tres siglos de vasallaje colonial bajo un "sistema de dilapidación" y una 
"monstruosa corrupción" los habían pervertido (Atkinson, 1836, p. 111). Como ciudadanos de una república independiente, los mexicanos tenían, por fin, una oportunidad inmejorable para cambiar. Solo debían evitar caer, voluntaria o involuntariamente, en el camino equivocado.

$\mathrm{El}$ camino equivocado al que los cronistas anglosajones hacían referencia era el retorno al absolutismo que había marchitado al país. Por ello, la Santa Alianza, que mantuvo su agresividad desde la consumación de la independencia de México hasta las Revoluciones de 1848, representaba un riesgo mayor. La defensa de la Doctrina Monroe, concepto británico del que los estadounidenses se apropiaron y que Gran Bretaña toleró a regañadientes, traslucía en los escritos de los cronistas. El liberalismo anglosajón rescataría a los mexicanos de la postración en que se encontraban y evitaría que cayeran nuevamente en garras del absolutismo. La descripción de un pueblo bueno, pero degradado, hizo de los cronistas agentes de la geopolítica. Permitió justificar un mayor involucramiento anglosajón en México. Esta justificación alcanzaría su cénit con el concepto del Destino Manifiesto de 1845, que cancelaría la inestable alianza anglosajona y la suplantaría con un proyecto netamente estadounidense.

\section{Referencias bibliográficas}

Atkinson, S. (1836)

Atkinson's casket: Gems of Literature, wit and sentiment. Philadelphia: Samuel Atkinson.

Beaufoy, M. (1828)

Mexican illustrations, founded upon facts (2 volúmenes). Londres: Carpenter \& Son.

Bernecker, W. L. (2003)

"Literatura de viajes como fuente histórica para el México decimonónico: Humboldt, inversiones e intervenciones" Tzintzun. Revista de estudios históricos, (38), 35-64.

Boehm de Lameiras, B. (1973)

Indios de Mexico y viajeros extranjeros, siglo XIX. México: Secretaría de Educación Pública.

Calderón de la Barca, M. (Frances Erskine Inglis). (1843)

Life in Mexico: during a residence of two years in that country (2 volúmenes). Boston: Charles C. Little \& James Brown.

Charles, J. L. (1836)

The rambler in Mexico. Nueva York: Harper \& Brothers.

Cramaussel, C. (1998)

Imagen de México en los relatos de viaje franceses (1821-1862). En 
J. Pérez Siller (Coord.), México-Francia: memoria de una sensibilidad común, siglos XIX-XX (pp. 333-365). México: Benemérita Universidad Autónoma de Puebla, Colegio de San Luis, Centro Francés de Estudios Mexicanos y Centroamericanos.

Cole, G. (1978) American travelers to Mexico, 1821-1972: A descriptive bibliography. Albany: Whitston Publishing Company.

Covarrubias, J. E. (1998)

Visión extranjera de México, 1840-1867: el estudio de las costumbres y de la situación social. México: Universidad Nacional Autónoma de México.

De la Garza, L. A. (2003)

En busca de una identidad: Carlo Vidua, un viajero piamontés del siglo XIX. México: Universidad Nacional Autónoma de México.

Duane, W. (1824)

The two Americas, Great Britain, and the Holy Alliance. Washington: Edward de Krafft.

Gage, T. (1677)

A new survey of the West-Indies: Or, the English American his travel by sea and land. Londres: A. Clark.

Gardiner, C. H. (1952)

Foreign travelers Accounts of Mexico, 1810-1910. The Americas, VIII (3), 321-351.

Gilliam, A. M. (1846)

Travels over the tablelands and cordilleras of Mexico. During the years 1843 and 44. Philadelphia: John W. Moore.

Gunn, D. W. (1974)

American and British writers in Mexico, 1556-1973. Austin: University of Texas Press.

Hardy, R. W. H. (1829)

Travels in the Interior of Mexico: In 1825, 1826, 1827, \& 1828. London:

H. Colburn and R. Bentley.

James, T. (1916)

Three years among the Indians and Mexicans. San Luis: Missouri Historical Society.

Kendall, G. W. (1847)

Narrative of the Texan Santa Fe expedition: Comprising a description of a tour through Texas, and across the great southwestern prairies (2 volúmenes). Nueva York: Harper \& Brothers.

Kohut, K. (2010)

Las primeras décadas del México independiente vistas y juzgadas por autores alemanes. Literatura Mexicana, XXI (1), 157-180. 
Lau Jaiven, A. (1994)

Retablo costumbrista: vida cotidiana y mujeres durante la primera mitad del siglo XIX mexicano según viajeros anglosajones. En R. Hernández Franyuti (Coord.), La ciudad de México en la primera mitad del siglo XIX (pp. 365-410). México: Instituto Mora.

Latrobe, C. J. (1836)

The rambler in Mexico: MDCCCXxxIv. London: RB Seeley and W. Burnside.

Levine, S. (2012)

Jorge Luis Borges and the translators of the nights. Translation Review, 77 (1), 21-27.

Lyon, G. F. (1828)

Journal of a residence and tour in the republic of Mexico in the year 1826 (2 volúmenes). Londres: John Murray.

Matthews, R. (2017)

The history of the provincial press in England. Nueva York: Bloomsbury.

Mayer, B. (1847)

Mexico as it was and as it is. Philadelphia: G.B. Zieber \& Company.

Niles, H. (1822)

Mexico. Nile's Register, XXII (1), 7-9.

Niles, J. M. (1825)

A view of South-America and Mexico, by a citizen of the United States

(Volumen 1). Nueva York: H. Huntington.

Ortega y Medina, J. A. (1953)

México en la conciencia anglosajona (2 volúmenes). México: Porrúa.

Penny, E. B. (1828)

A sketch of the customs and society of Mexico; in a series of familiar letters, and a journal of travels in the interior, during the years 1824, 1825, 1826. Londres: Longman \& Co.

Pierini, M. (2012)

Prólogo. México: memorias de un viajero. Isidore Löwenstern. México: Fondo de Cultura Económica.

Poinsett, J. R. (1824)

Notes on Mexico, made in the autumn of 1822. Philadelphia: H.C. Carey \& I. Lea.

Poinsett, J. R. (1825)

Notes on Mexico, made in the autumn of 1822. Londres: John Miller.

Pratt, M. L. (2008)

Imperial eyes: Travel writing and transculturation. Nueva York: Routledge. 
Rebok, S. (2014)

Humboldt and Jefferson: A transatlantic friendship of the enlightenment. Charlottesville: University of Virginia Press.

Robinson, W. D. (1821)

Memoirs of the Mexican revolution; including a narrative of the expedition of General Xavier Mina (Volumen 2). Londres: Lackington, Hughes, Harding, Mavor \& Lepard.

Ruxton, G. F. (1847)

Adventures in Mexico and the rocky mountains. Londres: John Murray.

Schake, K. (2017)

Safe passage: The transition from British to American hegemony. Cambridge: Harvard University Press.

Sherman, W. H. (2002)

Stirrings and searchings (1500-1720). En P. Hulme \& T. Youngs (Coords.), Cambridge companion to travel writing (pp. 17-36). Cambridge: Cambridge University Press.

Silva, J. (1946)

Viajeros franceses en México. México: Editorial América.

Singletary, O. (1962)

The Mexican war. Chicago: University of Chicago Press.

Stephens, J. L. (1843)

Incidents of travel in Yucatan. Nueva York: Harper \& Brothers.

Stoddard, R. H. (1859)

The life, travels and books of Alexander von Humboldt. Nueva York:

Rudd \& Carleton.

Thompson, W. (1846)

Recollections of Mexico. Nueva York: Wiley \& Putnam.

U.S. Congress. (1831)

Register of debates in Congress, VII. Washington: Gales \& Seaton.

Von Humboldt, A. (1814)

Political essay on the kingdom of New Spain. Londres: Longman, Hurst, Rees, Orme \& Brown.

Ward, H. G. (1829)

Mexico in 1827 (Volumen 1). Londres: Henry Colburn.

Whittaker, G. (1824)

Universal review; or, chronicle of the literature of all nations I. Londres: Geo. B. Whittaker. 